Published by Al-Nahrain College of Medicine P-ISSN 1681-6579

E-ISSN 2224-4719

Email: iraqijms@colmed-alnahrain.edu.iq

http://www.colmed-alnahrain.edu.iq

http://www.iraqijms.net

Iraqi JMS 2018; Vol. 16(2)

\title{
Cyperus Rotundus Tubers Extract Inhibits Stem Cell Markers Expression in Cervical and Human Glioblastoma Cancer Cell Lines
}

\author{
Zaynab S. Abdulghany $P h D$, Noah A. Mahmood $P h D$, Amer T. Tawfeeq $P h D$, Nahi Y. Yassen $P h D$ \\ Dept. of Molecular Biology, Iraqi Center for Cancer and Medical Genetics Research, Baghdad, Iraq
}

\begin{abstract}
Background Cancer stem cell markers known for their ability to induce tumor initiation, angiogenic activity, therapy resistance and metastasis formation. Plant extract potentially was used to treat cancer and/or target its genes. Cyperus rotundus tubers extract has been used in ancient as a folk medicine for its antibacterial, anti-diabetic and for other maladies for its antioxidant properties that have been estimated in modern medicine.

Objective

To determine the effects of total oligofalvonoids (TOF) extracted from Cyperus rotundus tubers against cervical cancer cells line (HeLa) and human glioblastoma (AMGM) cell line.

Methods

Cytotoxicity of TOF extract against both cancer cell lines was determined after $24 \mathrm{hr}$ of exposure and the best concentration of inhibition was $350 \mu \mathrm{g} / \mathrm{ml}$. Total RNA extracted from both cell lines after treated with TOF and the expression levels of cancer stem cell markers OCT3/4 as well as matrix metalloproteinasese MMP2 and MMP9 have been measured using quantitative real time polymerase chain reaction.

Results Cytotoxicity of TOF extract with concentration $(350 \mu \mathrm{g} / \mathrm{ml})$ shown to reduce the growth of cancer cell lines after $24 \mathrm{hr}$ of exposure. The expression level of OCT3/4 was highly significantly reduced in both AMGM and HeLa cells after treated with TOF and the fold change reduced from (15 to 0.03 ) and (10 to 0.09), respectively. On the other hand, the expression levels of MMP2 and MMP9 were significantly decreased in AMGM and HeLa cells treated with TOF extract with decreasing in fold change from (10.2 to 0.02) for MMP2 in AMGM cells and (1.85 to 0.5 ) for MMP9. And fold change of MMP2 expression in HeLa cells was decreased after treated with TOF from (11.1 to 0.01 ) and for MMP9 (11.43 to 0.08).

Conclusion The result indicates that the inhibition of cancer stem cell markers OCT3/4 and MMP2 and MMP9 may provide a novel strategy to treat cancer using a natural plant extract.

Keywords Citation Cancer stem cell markers, AMGM cells, Hela cells

Abdulghany ZS, Mahmood NA, Tawfeeq AT, Yassen NY. Cyperus Rotundus Tubers extract inhibits stem cell markers expression in cervical and human glioblastoma cancer cell lines. Iraqi JMS. 2018; 16(2): 159165. doi: 10.22578/IJMS.16.2.7
\end{abstract}

List of abbreviations: AMGM = human glioblastoma cell line, AMN3 = Mice mammary adenocarcinoma cell line, $\mathrm{CSC}=$ Cancer stem cell, $\mathrm{ct}=$ threshold cycle, $\mathrm{DMSO}=$ Dimethysulphoxide, $\mathrm{ECM}=$ Extracellular matrix, ER-alpha = Estrogen alpha receptor, HeLa cells = Human cervical cancer cell line, MCF-7 = Human breast adenocarcinoma cell line (estrogen, progesterone receptors +, HER2-), MDA-MB-231 = Antiproliferative human breast cancer cell line (triple negative), MMP = Matrix metalloproteinase (group of enzymes), MTT= 3-(4,5-dimethylthiazol-2-yl)-2,5-diphenyltetrazolium bromide dye, mRNA = Messenger ribonucleic acid, OCT3/4 = Octamer-binding transcription factor, $\mathrm{PCR}=$ Polymerase chain reaction, $\mathrm{qPCR}=$ Quantitative real time PCR, RMPI1640 = Roswell Park Memorial Institute, TOF = Total oligomeric flavonoids

\section{Introduction}

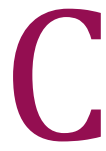

ancer is one of the most common diseases worldwide, and ranks the second most common cause of death following cardiovascular diseases. Chemotherapy is able to kill some cancer cells especially the more rapidly replicating tumor cells, but they were nonspecific, characterized by low therapeutic index and associated with a wide range of side effects. The anticancer field still searching for herbal treatments to avoid these side effects; the primary tumor and death related cancer result from tumor spread and metastasis (1). Progression of metastasis starts after cancer cell detachment from the primary tumor, basement membrane degradation and cancer cell invasion into the 
surrounding stroma then transport through the vascular or lymphatic system spread to distant organs ${ }^{(2)}$. The invasion depends how cancer cells degrades the extracellular matrix (ECM), which is composed of collagen, proteoglycans, fibronectin, laminin and other glycoproteins and when intact acts as a barrier to block cancer cell invasion (3).

From last century, cancer research studies have been used traditional plants in an effort to discover new therapeutic agents that lack the toxic side effects associated with current chemotherapeutic agents ${ }^{(4)}$. In Asian countries, the rhizomes of Cyperus rotundus (C. rotundus) was used as traditional folk medicines for the treatment of stomach and bowel disorders, and inflammatory diseases, have been widely, investigated ${ }^{(5)}$. Then the new researches have demonstrated its important using as antimicrobial, anti-malarial, anti-oxidant, and antidiabetic compounds isolated and identified from C. rotundus (6). Phytochemical studies mentioned that $\mathrm{C}$. rotundus contains alkaloids, flavonoids, tannins, starch, glycosides and furochromones, and many novel sesquiterpenoids (7).

Matrix metalloproteins (MMPs) play role in cancer migration, invasion, metastasis and angiogenesis (8). Activities of MMPs are regulated at levels of mRNA transcription and stability control in that they will control cell fate and alter developmental and pathological outcomes ${ }^{(9)}$. Both MMP-2 (gelatinase A) and MMP-9 (gelatinase $B$ ) belong to the gelatinase subfamily, which is a group of proteolytic enzymes distinguished by their fibronectin-like gelatin-binding domain (10). Also, their expressions have been increased in most types of cancer for example, breast, prostate, colon and others ${ }^{(10,11)}$.

The nuclear transcription factor OCT3/4 is a novel marker with high sensitivity and specificity expressed in embryonic cells, germ cells, and stem cells. Also, it is an important regulator of tissue specific gene expression, and a critical amount of OCT3/4 is required to maintain stem cell replication ${ }^{(12)}$.
To study the effect of total oligoflavoniods (TOF) inducing apoptosis to cancer cell line, this project was designed to determine the effect of TOF on HeLa and AMGM cancer cell lines and on the expression of OCT3/4, MMP2 and MMP9 genes expression before and after treatment by measuring the fold change using real time qPCR.

\section{Methods}

\section{Plant extract preparation}

Plant has been collected in previous study as presented in the research of ${ }^{(13)}$. Briefly, tubers part of $C$. rotundus, were harvested in summer especially between May and late September. Botanical identification was carried out by Prof. Dr. Ali H.E. Al Mosawi, Head of Iraqi Herbarium and Professor in plant taxonomy, Biology Department, College of Science, Baghdad University in identification the genus and species of the herb as a Cyperus rotundus.

The cytotoxicity of the plant also study and the optimal inhibition concentration toward cancer cell line also described previously in study of (14), in short TOF were tested against two different cancer cell liens AMGM and AMN3, were tested and cultured in the presence of TOF extracts at different concentrations extended from $50 \mu \mathrm{g} / \mathrm{ml}$ to $500 \mu \mathrm{g} / \mathrm{ml}$ with 50 $\mu \mathrm{g} / \mathrm{ml}$ increment each time for $24 \mathrm{hr}$. Cells viability was determined by MTT assay and calculated as a percentage of control untreated cells. And the results of previous study (14) mentioned that TOF inhibited both AMGM and AMN3 cancer cells proliferation by $67.09 \%$ and $52.41 \%$ at concentration of $350 \mu \mathrm{g} / \mathrm{ml}$ during incubation time of $24 \mathrm{hr}$, then we continued from this point.

\section{Cell line culture maintenance and seeding}

Two types of human cancer cell lines have been selected, human cerebral glionlastomamultiform (AMGM) and human cervical cancer cell line (HeLa), these cell lines were kindly supplied by the Experimental Therapy Department, Iraqi Center for Cancer and Medical Genetics Research Center (ICCMGR). These cell lines were propagated and 
maintained on RPMI640 medium (US biological, USA) using the protocol ${ }^{(15)}$. To this media, 10\% fetal bovine serum (Cellgro, USA) and $1 \%$ Pencillin/ Strptomycin (Cellgro, USA) were added and then incubated at $37{ }^{\circ} \mathrm{C}$ in a humidified incubator (Memmert, Germany) with $5 \% \mathrm{CO}_{2}$. The monolayer cell culture formed in the culturing flasks, which can be observed under an inverted microscope (Lycia). The cells were subcaultered after they had achieved $80-90 \%$ confluency and trypsinized to detached from the flask and to be reday for separating and seprading on the petri disch 5 $\mathrm{ml}$. Three replicates of the TOF optimal concentration $350 \mu \mathrm{g} / \mathrm{ml}$ was used and another three replicates for the control untreated cells. After exposure to TOF for $24 \mathrm{hrs}$, the cells were collected and centrifuged. The pellet was stored in deep freezer (GFL, Germany) at $-80{ }^{\circ} \mathrm{C}$ to be ready for next step. These steps were carried out according to ${ }^{(15)}$ guidelines.

\section{RNA extraction}

Transcript levels of interested genes were examined by quantitative real-time PCR. Total RNA extraction has been carried out depending on the manual protocol using AccuZol ${ }^{\mathrm{TM}}$ total RNA Extraction Solution (Bioneer, South Korea). The concnetrations were recorded using nanodrop spectrophotometry (Quawell, UK).

\section{Primer selection}

Primers were designed for each gene using $\mathrm{NCBI} /$ primer-BLAST and its specificity for each gene investigated were verified using BLAST and single peak disassociation curve. Optimum annealing temperature was optimized over range of different temperature extended from $50 \circ \mathrm{C}$ to $62{ }^{\circ} \mathrm{C}$ using conventional PCR (Sure Cycler 8800 Thermal Cycler, Agilent technologies, USA). One step KAPA real time PCR kit has been used to determine the expression of OCT3/4, MMP2 and MMP9 in HeLa and AMGM cell lines before and after treated with TOF extract.

The sequences of specific primers used for determination of OCT3/4, MMP2 and MMP9 genes as follow: for OCT3/4 Forword:
ATGTGGTCCGAGTGTGGTTC

Reverse: ACAGTGCAGTGAAGTGAGGG. For MMP2, Forward: AAGGACAGCCCTGCAAGTTT Reverse: GTTCCCACCAACAGTGGACA and for MMP9, Forward: GGTGATTGACGACGCCTTTG Reverse: GGACCACAACTCGTCATCGT. Beta-actin gene was used as a housekeeping gene for normalizing the results ${ }^{(16)}$.

\section{Perform Real time-PCR}

For quantitative reverse transcriptase PCR (qRT-PCR), one-step SYBR green kit was used (one-step SYBR Fast, KAPA Biosystems, USA) using the primers of each gene in reveres transcription (RT) step for cDNA synthesis and for amplification. Thermal profile consists of 42 ${ }^{\circ} \mathrm{C}$ for $5 \mathrm{~min}$ to synthesize cDNA, $95{ }^{\circ} \mathrm{C}$ for $3 \mathrm{~min}$ to deactivate reverse transcriptase, followed by 40 cycles at $94{ }^{\circ} \mathrm{C}$ for 15 seconds, 30 seconds at $60{ }^{\circ} \mathrm{C}, 59{ }^{\circ} \mathrm{C}$, and $58{ }^{\circ} \mathrm{C}$ for 20 seconds to anneal primers (according to each gene optimum). Fold expression for each gene was determined using $\Delta \Delta C$ t method in comparison with $\beta$-actin gene as a housekeeping gene ${ }^{(17)}$.

\section{Statistical analysis}

The statistical significance was determined using the unpaired t-test. Probability less than 0.05 was considered as indicative of significance as compared to the control group. The data collected from triplicate for each gene. The expression of mRNA was assessed by evaluating threshold cycle $(\mathrm{Ct})$ values. The $\mathrm{Ct}$ values were normalized with the expression levels of Beta-actin and the relative quantity of mRNA specific to each of the target genes was calculated using the 2- $\Delta \Delta C T$ method according to ${ }^{(17)}$ methods.

\section{Results}

Quantitative real time PCR assay was analyzed the mRNA expression of OCT3/4, MMP2 and MMP9 genes in AMGM and HeLa cell lines before and after treatment with TOF extract. The calculation of gene expression fold change was carried out using relative quantification method. This method depends on 
normalization of $\mathrm{Ct}$ values calculating the $\Delta \mathrm{Ct}$ which is the difference between the mean $\mathrm{Ct}$ value of target gene expression and that of beta-actin. Then to calculate the gene expression folds in relation to the housekeeping genes the result of 2- $\Delta \mathrm{Ct}$ of each exposure cells in relation to that of control group untreated cell lines ${ }^{(17)}$.

Expression of $0 \mathrm{OCT} 3 / 4, \mathrm{MMP} 2$ and MMP9 in treated AMGM cell line with TOF

Expression level of OCT3/4, MMP2 and MMP9 genes have been detected in AMGM (human glioblastoma cell line) before and after treatment with TOF extract using quantitative real time PCR. The results demonstrated that the expression levels of OCT3/4, MMP2 and MMP9 genes were reduced in AMGM cell line when treated with TOF extract compared with untreated cells. The fold changes in expression of OCT3/4 was reduced from 15 to 0.03 with highly significant probability $(P=0.0008)$. While, the fold changes in MMP2 gene was reduced from 10 to 0.02 with high significant probability $(P=0.0001)$. On the other hand, MMP9 fold expression changed from 1.8 to 0.5 after treated with TOF extract with significant probability $(P=0.0028)$ as presented in Table 1 .

Expression of OCT3/4, MMP2 and MMP9 in treated HeLa cell line with TOF

Expression levels of OCT3/4, MMP2 and MMP9 gene have been detected in HeLa cell line before and after treated with TOF using quantitative real time $P C R$. The results that obtained determined that OCT3/4, MMP2 and MMP9 genes reduced expression in HeLa cell lines after treated with TOF. The fold changes in expression of OCT3/4 was 10 before treatment and reduced to 0.09 after treated cells with TOF, while fold changes of MMP2 gene was 11times and reduced to 0.01 after treatment and MMP9 gene expression level was 11 times and reduced to 0.08 after treatment with TOF with high significant probability 0.0001 for all the genes, these results presented in table 1 .

Table 1. Fold change in genes expression before and after treated AMGM and HeLa cancer cell lines with TOF extract

\begin{tabular}{cccccc}
\hline $\begin{array}{c}\text { Cell } \\
\text { lines }\end{array}$ & Genes & $\begin{array}{c}\text { Fold expression } \\
\text { before } \\
\text { treatment }\end{array}$ & $\begin{array}{c}\text { fold expression } \\
\text { after treatment } \\
\text { with TOF }\end{array}$ & $\begin{array}{c}\text { P value } \\
(\mathbf{p}<0.05)\end{array}$ & $\begin{array}{c}\text { Up / Down } \\
\text { expression after } \\
\text { treatment with } \\
\text { TOF }\end{array}$ \\
\hline \multirow{2}{*}{ AMGM } & OCT3/4 & 15.7 & 0.03 & $0.0008^{*}$ & DOWN \\
& MMP2 & 10.2 & 0.02 & $0.0001^{*}$ & DOWN \\
& MMP9 & 1.85 & 0.5 & $0.0028^{*}$ & DOWN \\
HeLa & OCT3/4 & 10.3 & 0.09 & $0.0001^{*}$ & \\
& MMP2 & 11.11 & 0.01 & $0.0001^{*}$ & \\
\hline
\end{tabular}

* means there are statistically significant $(p \leq 0.05)$

\section{Discussion}

According to emphasize the use of herbal medicines in the treatment of cancer, in this study the effect of TOF on the expression of genes OCT3/4, MMP2 and MMP9 in AMGM and HeLa cancer cell lines were determined and the data showed that TOF extract has effect on expression of genes by decreasing genes expression that may be related to reduction in the rate of cell division, and this loss leads to the development of cancerous tissue. The results can be used as an example 
of the use of herbal medicines in anticancer studies ${ }^{(18)}$. Complementary medicine therapies can be beneficial in cancer control and antitumor compounds suitable for further projects to be occurred.

Several studies mentioned the use of medicinal plant in cancer treatments one of these are the using of Bangladeshi medicinal plants (Emblica officinalis, Aegle marmelos, Vernonia anthelmintica, Oroxylum indicum, Argemone mexicana) as antiproliferative human breast tumor cell lines MDA-MB-231, this leads to the increase of ER-alpha mRNA accumulation (a marker of neoplastic status) ${ }^{(19)}$.

While in recent study ${ }^{(20)}$ the Iranian medicinal plant N. binaloudensis hexane extract effect on the expression of adenosine deaminase and ornithine decarboxylase 1 genes in two breast cancer cell lines (MCF-7, MDA-MB-231). They found that the extract play as antiproliferative of breast cancer cell lines and decrease in the expression of ornithine decarboxylase 1 and adenosine deaminase genes (these enzymes participates in purines metabolism and has role in development of immune system and maturation of mammalian cells) reduction was 4.9 fold - 3.5 fold in MCF-7 cell line and 3.6 fold - 2.6 fold in MDA-MB-231 cell line, respectively. From different studies that mentioned the role of active compounds present in herbs have role in cancer treatment, a study of (21) mentioned that two new sesquiterpenes were isolated from the soluble fraction of rhizomes of Cyperus rotundus L. were evaluated for their cytotoxic activities against human ovarian cancer cells and endometrial adenocarcinoma cells (Ishikawa). The effects of $C$. rotundus on cell proliferation and apoptosis induction in murine and human leukemia cells were also examined in other cell lines. Besides, the main phenolic (orientin) compound in the methanol extract was isolated by chromatographic methods and was determined by spectroscopic data analysis and by a comparison with the literature (22).

Several studies have shown that consumption of certain foods and herbs can inhibit the growth of cancer cells. Dixon and his team workers studied the effects of curcumin as anti-metastatic breast cancer (23). Curcumin inhibits the transcriptional network in stages and thus prevents the cell proliferation ${ }^{(24)}$. In another study of cell cycle arrest and growth of curcumin on gastric cancer cells was observed (25). All these studies prove the importunacy of herbs and their active compounds in cancer treatment and managements of diseases.

In conclusion, C. rotundus shows anti-cancer effects in AMGM and HeLa cells. The effect was mediated through the inhibition of cell proliferation of these cell lines suggesting that it can complement current chemotherapeutic treatment. This study confirms the demonstrating the potential applications of $C$. rotundus as an anti-cancer drug and thus highlight further research on cancer drug discovery.

\section{Acknowledgments}

The authors regret to advice of the passing of Dr. Zaid A. Munium prior to publication. And we would like to thank all the technician staff in the lab. who helped us in this project.

\section{Authors contribution}

Dr. Abdulghany: did the actual lab work (RNA extraction, real time PCR running times), statistical analysis and writing of draft. Dr. Mahmood: conducted the seeding and maintenance of cell lines plus the molecular work and writing the discussion. Dr. Tawfeeq: extraction of plant, drafting the article and revising it critically for important intellectual content. Dr. Yassen: giving the advice in writing style and the correcting the theory of the work.

\section{Conflict of interest}

No potential conflicts of interest.

\section{Funding}

The author received no specific grant from any funding agency for preparing this project.

\section{References}

1. Ferlay J, Soerjomataram I, Ervik M, Dikshit R, Eser S, Mathers C et al. GLOBOCAN 2012 v1.0, Cancer incidence and mortality worldwide: IARC CancerBase No. 11 [Internet]. Lyon, France: International Agency for Research on Cancer; 2013 Available from: http://globocan.iarc.fr. 
2. van Zijl F, Krupitza G, Mikulits W. Initial steps of metastasis: Cell invasion and endothelial transmigration. Mutat Res. 2011; 728(1-2): 2334. doi: 10.1016/j.mrrev.2011.05.002.

3. Martin TA, Ye L, Sanders AJ, et al. Cancer invasion and metastasis: molecular and cellular perspective. In: Madame Curie Bioscience Database. Austin (TX): Landes Bioscience; 20002013.

4. Jun HJ, Bronson RT, Charest A. Inhibition of EGFR induces a c-MET-driven stem cell population in glioblastoma. Stem Cells. 2014; 32(2): 338-48. doi: $10.1002 /$ stem.1554.

5. Zhu M, Luk HH, Fung HS, et al. Cytoprotective effects of Cyperus rotundus against ethanol induced gastric ulceration in rats. Phytother. Res. 1997; 119(5): 392-4. doi: https://doi.org/10.1002/(SICI)10991573(199708)11:5<392::AID-PTR113>3.0.CO;21.

6. Dang GK, Parekar RR, Kamat SK, et al. Antiinflammatory activity of Phyllanthus emblica, Plumbago zeylanica and Cyperus rotundus in acute models of inflammation. Phytother Res. 2011; 25(6): 904-8. doi: 10.1002/ptr.3345.

7. Sayed HM, Mohamed MH, Farag SF, et al. A new steroid glycoside and furochromones from Cyperus rotundus L. Nat. Prod. Res. 2007; 21(4): 343-50. doi: 10.1080/14786410701193056.

8. Gialeli C, Theocharis AD, Karamanos NK. Roles of matrix metalloproteinases in cancer progression and their pharmacological targeting. FEBS J. 2011; 278(1): 16-27. doi: 10.1111/j.17424658.2010.07919.x.

9. Gong Y, Chippada-Venkata UD, Oh WK. Roles of matrix metalloproteinases and their natural inhibitors in prostate cancer progression. Cancers (Basel). 2014; 6(3): 1298-1327. doi: 10.3390/cancers6031298.

10.Brehmer B, Biesterfeld S, Jakse G. Expression of matrix metalloproteinases (MMP-2 and -9) and their inhibitors (TIMP-1 and -2) in prostate cancer tissue. Prostate Cancer and Prostatic Diseases. 2003; 6(3): 217-22. doi: 10.1038/sj.pcan.4500657.

11. Polette $M$, Clavel $C$, Cockett $M$, et al. Detection and localization of mRNAs encoding matrix metalloproteinases and their tissue inhibitor in human breast pathology. Invasion Metastasis. 1993; 13(1): 31-7.

12.Jones TD, Ulbright TM, Eble JN, et al. OCT3/4 is a sensitive and specific marker for testicular seminoma and embryonal carcinoma. Modern Pathol. 2004; 17(Suppl. 1): 160A.

13.Al-Hilli Z, AL-Ahammari A, Al-Jumaily $E$, et al. The antiangiogenic effect of polyphenolic fraction of Cyperus rotundus L. on human Glioblastoma cell line. First Scientific Conference on Nanotechnology, Advanced Material and Their applications, At University of Technology, Baghdad, Iraq, Volume: 1. Conference Paper. 2009.

14.Tawfeeq A, Al-Hilli Z, Yaseen N. Total oligomeric flavonoids (TOF) of the herb tubers Cyperus rotundus induce growth inhibition and apoptosis in some cancer cell lines, a preliminary study. Conference: 23 ${ }^{\text {rd }}$ ECDO Euroconference on Cell Death Pathways and Beyond, At Geneva, Switzerland. Conference Paper. 2015

15. Freshney R. Culture of animal cells: a manual of basic technique and specialized applications. $6^{\text {th }}$ ed. NewYork, NY: Wiley-Blackwell; 2010.

16. Rebouças EL, Costa JN, Passos MJ, et al. Real time PCR and importance of housekeepings genes for normalization and quantification of mRNA expression in different tissues. Brazilian Arch of Biol Technol. 2013; 56(1): 143-54. doi: https://dx.doi.org/10.1590/S151689132013000100019.

17. Livak KJ, Schmittgen TD. Analysis of relative gene expression data using real-time quantitative PCR and the 2(-Delta DeltaC(T)) Method. Methods. 2001; 25(4): 402-8. doi: 10.1006/meth.2001.1262.

18. Mazzio EA, Soliman KF. In vitro screening for the tumoricidal properties of international medicinal herbs. Phytother Res. 2009; 23(3): 385-98. doi: 10.1002/ptr.2636.

19.Lambertini E, Piva R, Khan MTH, et al. Effects of extracts from Bangladeshi medicinal plants on in vitro proliferation of human breast cancer cell lines and expression of estrogen receptor alpha gene. Int J Oncol. 2004; 24(2): 419-23. doi: https://doi.org/10.3892/ijo.24.2.419.

20.Afshar AS, Nematpour FS, Meshkani M, et al. Growth inhibition of human breast cancer cells and down-regulation of ODC1 and ADA genes by Nepeta binaloudensis. Revista Brasileira de Farmacognosia. 2017; 27(1): 84-90. doi: https://dx.doi.org/10.1016/j.bjp.2016.07.005.

21. Ryu B, Kim HM, Lee JS, et al. Sesquiterpenes from Rhizomes of Cyperus rotundus with Cytotoxic Activities on Human Cancer Cells in vitro. Helvetica. 2015; 98(10): 1372-80. doi: http://dx.doi.org/10.1002/hlca.201500117. 
22.Soumaya KJ, Zied G, Nouha N, et al. Evaluation of in vitro antioxidant and apoptotic activities of Cyperus rotundus. Asian Pac J Trop Med. 2014; 7(2): 105-12. doi: 10.1016/S19957645(14)60004-3.

23.Dixon-Shanies D, Shaikh N. Growth inhibition of human breast cancer cells by herbs and phytoestrogens. Oncol Rep. 1999; 6(6): 1383-7. doi: https://doi.org/10.3892/or.6.6.1383.

24.Mudduluru G, George-William N, Muppala S, et al. Curcumin regulates miR-21 expression and inhibits invasion and metastasis in colorectal cancer. Biosci Rep. 2011; 31(3): 185-97. doi: 10.1042/BSR20100065.

25.Lim $T$, Lee $S$, Huang $Z$, et al. Curcumin suppresses proliferation of colon cancer cells by targeting CDK2. Cancer Prev Res (Phila). 2014; 7(4): 466-74. doi: 10.1158/1940-6207.CAPR-130387.

\section{Correspondence to Zaynab S. Abdulghany}

E-mail: zaynab.saad@iccmgr.org

Received Jul. $2^{\text {nd }} 2017$

Accepted Nov. 14 2017 